Vol 11, Issue 1, 2018

\title{
THE EFFECT OF LUNASIN FROM INDONESIAN SOYBEAN EXTRACT ON INDUCIBLE NITRIC OXIDE SYNTHASE AND $\beta$-CATENIN EXPRESSION IN DEXTRAN SODIUM SULFATE-INDUCED MICE COLON
}

\author{
KUSMARDI KUSMARDI ${ }^{1}$, NESSA NESSA ${ }^{2 *}$, ARI ESTUNINGTYAS ${ }^{2}$, ARYO TEDJO ${ }^{3}$, PUSPITA EKA WUYUNG ${ }^{1}$ \\ ${ }^{1}$ Department of Anatomical Pathology, Faculty of Medicine, Universitas Indonesia, Indonesia. ${ }^{2}$ Department of Pharmacology and \\ Therapeutic, Faculty of Medicine, Universitas Indonesia, Indonesia. ${ }^{3}$ Department of Chemical Medicine, Faculty of Medicine, Universitas \\ Indonesia, Indonesia. Email: nessa91nessa@gmail.com
}

Received: 04 August 2017, Received and Accepted: 23 September 2017

ABSTRACT

Objective: Inflammatory bowel diseases are idiopathic inflammatory disorders of the gastrointestinal tract. Chronic inflammation that occurs in the colon can develop into colon cancer. Lunasin has been known to resist inflammatory reactions induced by lipopolysaccharide in vitro. The role of lunasin as anti-inflammatory in vivo is not widely known. In this study, we analyzed the effect of lunasin from Indonesian soybean to decrease the risk of inflammation by analyzing the expressions of inducible nitric oxide synthase (iNOS) and $\beta$-catenin.

Methods: A total of 30 mice are divided into six groups. Normal group was not induced by dextran sodium sulfate (DSS). The other groups were induced by DSS 2\% through drinking water for 9 days. After 9 days, negative group did not receive any treatment, besides the other groups received treatment given lunasin dose $20 \mathrm{mg} / \mathrm{kg} \mathrm{BB}$ and $40 \mathrm{mg} / \mathrm{kg} \mathrm{BB}$, commercial lunasin, and positive given aspirin. Treatment was performed for 5 weeks. Immunohistochemistry scores of iNOS and $\beta$-catenin proteins were analyzed using statistical tests.

Results: Expression of iNOs decreased significantly $(\mathrm{p}<0.05)$ with an average score of 60.134 and 35.473. Expression of $\beta$-catenin decreased significantly $(\mathrm{p}<0.05)$ with an average score of 15.58 and 11.131 .

Conclusion: Lunasin dose $20 \mathrm{mg} / \mathrm{kg} \mathrm{BW}$ and $40 \mathrm{mg} / \mathrm{kg} \mathrm{BB}$ were able to inhibit inflammation by decreasing the expressions of iNOS, and $\beta$-catenin.

Keywords: Inflammation, Lunasin, Inducible nitric oxide synthase, $\beta$-catenin

(c) 2018 The Authors. Published by Innovare Academic Sciences Pvt Ltd. This is an open access article under the CC BY license (http://creativecommons. org/licenses/by/4. 0/) DOI: http://dx.doi.org/10.22159/ajpcr.2018.v11i11.21811

\section{INTRODUCTION}

Inflammatory bowel disease (IBD) is a condition that describes chronic inflammation of the gastrointestinal tract that can be divided into two major disorders, namely, ulcerative colitis (UC) and Crohn's disease (CD) [1]. Both types of this disease are distinguished based on the location of the inflammation [2]. In UC disease, inflammation occurs only in the colon. While $\mathrm{CD}$, inflammation can occur in all parts of the digestive tract from mouth to anus [1].

The first highest incidence of IBD cases occurs in patients with an age range between 15 and 30 years. The second highest incidence occurred between the ages of 50 and 80 years. The prevalence of IBD is higher in the western states than in developing countries [1]. About 1-2 million people in the United States are estimated to have either UC or CD, with insects ranging from 70 to 150 cases per 100,000 individuals. Whereas in Europe, the incidence of UC ranges from 7.3 cases per 100,000 population and CD incidence is about 5.8 cases per 100,000 population [3].

IBD can develop into colon cancer known as colitis-associated cancer (CAC). This cancer is usually difficult to treat, thus increasing the mortality rate [4]. A study reported more than $20 \%$ of IBD patients can develop into colon cancer and $50 \%$ of patients die of colon cancer [5]. These patients reported increased gene expression that contributed to the inflammatory process [6]. Patients with a potentially higher UC develop into colon cancer compared to CD patients. Increased risk of IBD into colon cancer also occurs in IBD patients who have a family history of colon cancer [7].

The increased risk of IBD for developing CAC depends on the duration and extent of inflammation [1]. Area of inflammation can be driven by the accumulation of immune cells and inflammatory mediators such as cytokines, chemokines, growth factors, lipid molecules, reactive oxygen species (ROS), and nitrogen species. The interactions between immune cells, inflammation and cytokines lead to signal stimulation that helps the development, growth, and metastases of tumor cells. A clear link exists between inflammation (IBD) and colon cancer [4].

Inflammation in the epithelial cells of the colon can lead to the formation of inducible nitric oxide synthase (iNOS) and cyclooxygenase-2 (COX-2), which resulted in upregulation of the production of nitric oxide (NO) and prostaglandin E2 (PGE2). Both of these molecules cause an increased ROS. ROS can cause a variety of damage to protooncogene and tumor suppressor gene. The damages caused by ROS stimulate gene expression in normal epithelial cells into cells preneoplastic and neoplastic cells [8]. $\beta$-catenin is one protooncogene associated with cancer development colon cancer [9]. Mutations of $\beta$-catenin gene result in $\beta$-catenin protein overexpression in cytoplasm and nuclear of colorectal crypt epithelial cell [10]. Inflammation models can be obtained by induction of dextran sodium sulfate (DSS) as a compound that stimulates inflammation $[11,12]$.

One of the utilization of natural ingredients that are known to have antiinflammatory effect is soybean. An agent that had been identified in soybean is lunasin [13-15]. Lunasin peptide also can be found in wheat and dairy products such as soy milk, tofu, tempeh, whole wheat bread, and others $[14,15]$.

In vitro studies have demonstrated the effect of lunasin to suppress inflammatory reactions induced by lipopolysaccharide (LPS). The ability of lunasin in suppressing the inflammatory activity thought to be used as a deterrent to the development of colon cancer-related inflammation. Some studies indicate lunasin have the potential 
to reduce the production of proinflammatory cytokines such as interleukin-6 (IL-6) and tumor necrosis factor- $\alpha$ (TNF- $\alpha$ ) as well as proinflammatory mediators, such as PGE2, through modulation of COX-2/PGE2 and iNOS/NO pathway by inhibiting NF- $\kappa$ B pathway in RAW 264 macrophage cells induced by LPS [16-18].

The role of lunasin as an anti-inflammatory in vivo is not widely known. Research on the expression of $\beta$-catenin as a result of the regulation of iNOS in colorectal epithelial cells of mice is expected to provide some information regarding the effect of lunasin on the expression of three proteins to inhibit inflammation and potentially reduce the risk of colon cancer, particularly those initiated by inflammation (IBD).

\section{METHODS}

\section{Plant material and extraction}

Soybean was obtained from Indonesian Legumes and Tuber Crops Research Institute Malang of East Java, Indonesia. Soybean variety used in this study was Grobogan because it contents the highest protein than other varieties (to reach $43.9 \%$ ).

Soybean seed was pressed to obtain free oil defatted soybean. The defatted soybean Grobogan was macerated with aquadestilated $(1: 5,30 \mathrm{~min})$ and filtrated 3 times. Filtrate was dried with rotary vapor resulted soybean extract. The result was tested by high-performance liquid chromatography (HPLC) to determine the content of lunasin according to previous study [19].

\section{HPLC analysis of lunasin}

Analysis of lunasin in extract was tested by HPLC. $100 \mathrm{mg}$ extract is dissolved in $8 \mathrm{~mL}$ of aquadest, then the solution is dismonicated for $30 \mathrm{~min}$ and then added aquadest up to $10 \mathrm{~mL}$ (10.000 ppm solution). The solution was then centrifuged at $12,000 \mathrm{rpm}$ for $30 \mathrm{~min}$ and the filtrate was filtered with a $0.22 \mu \mathrm{m}$ millipore filter and obtained a clear and colorless solution. The solution was determined lunasin levels by HPLC method using C18 column and UV-Vis detector, using acetonitrile-water phase: Water at 5:95 ratio, retention time $35 \mathrm{~min}$, wavelength $295 \mathrm{~nm}$, injection volume $20 \mu \mathrm{L}$, and motion phase velocity $2 \mathrm{~mL} / \mathrm{min}$ [19]

\section{Commercial lunasin}

Commercial lunasin was produced by Reliv Internatioal Inc. USA and imported by PT. Reliv Indonesia. Commercial lunasin used in this research is the most pure, concentrated form of lunasin ever produced. It contents 125 grams of high-quality soy protein.

\section{Animal}

A total of 30 male Swiss-Webster mice (8-10 weeks) with an average weight of $20 \mathrm{~g}$ were supplied by the Health Research and Development Agency of the Ministry of Health of the Republic of Indonesia. The mice were kept in independent ventilation cages $(48 \mathrm{~cm} \times 35 \mathrm{~cm} \times 20 \mathrm{~cm})$ with free access to food and water under controlled humidity $(55 \pm 5 \%)$, light/dark cycle $(12 / 12 \mathrm{~h})$, and temperature $\left(23 \pm 1^{\circ} \mathrm{C}\right)$. The mice were carefully examined to ensure that they are in healthy conditions and acclimatized for 1 week before any experimental procedure was performed. All protocols and surgical procedures were approved by the animal care and use committee of the faculty of medicine of the University of Indonesia.

\section{Induction of inflammation}

Induction of inflammation procedure was adopted from Perse et al: Mice were given DSS 2\% drinking water for 9 days [12].

\section{Experimental groups}

A total of 30 mice were randomized into the following six groups: 5 mice in normal group; 5 mice in negative group, only received induction $2 \%$ DSS for 9 days; 5 mice positive group received a daily oral aspirin suspension at a dose of 42,25 mg/kgBW after 9 days induction; 5 mice received and SE2 a daily oral soybean extract contained lunasin at a dose of 20 and $40 \mathrm{mg} / \mathrm{kgBW}$ after 9 days induction; respectively; commercial lunasin treatment groups (CL), which received daily oral commercial lunasin at a dose of $16,25 \mathrm{mg} / \mathrm{kgBW}$, after 9 days induction. After 5 weeks, the mice were sacrificed, and colon tissues of mice were taken.

\section{Tissue sample preparation}

Colon tissues of mice were cleaned from the lumen of the colon with water. Tissues were fixed with $10 \%$ of buffered neutral formalin and embedded in paraffin blocks.

\section{Immunohistochemistry staining}

Tissue sample was cut to a thickness of $3-5 \mu$ m for immunohistochemistry staining. The specimens were deparaffinized with Xylol I, II, and III for 5 minutes each, then rehydrated with absolute alcohol, $90 \%$ alcohol and 70\% alcohol for 5 minutes each. After deparaffination and rehydration, specimens were spilled by $0.5 \%$ of $\mathrm{H}_{2} \mathrm{O}_{2}$ to eliminate endogenous peroxide for $30 \mathrm{~min}$ at room temperature. To block nonspecific antigen sites, specimens were incubated for $10 \mathrm{~min}$ in trisEDTA at $96^{\circ} \mathrm{C}$ temperature. Specimens were incubated with rabbit polyclonal antibodies of iNOS (1:100 dilution) or rabbit polyclonal $\beta$-catenin (1:300 dilution) for 1 hours at room temperature. Specimens were then incubated with the appropriate secondary antibody for 15 minutes, followed by incubation with HRP-conjugated streptavidin for 15 minutes. Proteins visualized using 3,3' diaminobenzidine for 2 min. The specimens were added counterstain with hematoxyllin, dehydrated, clearing, and mounting.

\section{Evaluation of immunohistochemistry staining}

iNOS expressions in the cytoplasm and $\beta$-catenin expressions in the nuclear of colon crypt epithelial cells were scored semiquantitatively using $\mathrm{H}$-score assessment at $\times 400$ magnification. The total number of cells in each field and the number of cells stained at each intensity were counted. The average percent positive was calculated and the following formula [20]:

$S=(S S S \times S P)+(I S S \times I P)+(W S S \times W P)+(N S S \times N P)$

S: Total score,

SSS: Strong staining score (3),

SP: Strong percentage (0-100\%),

ISS: Intermediate staining score (2),

IP: Intermediate percentage (0-100\%),

WSS: Weak staining score (1),

WP: Weak percentage (0-100\%),

NSS: Negative staining score (0),

NP: Negative percentage (0-100\%).

\section{Statistical analysis}

The average total scores are reported as the mean rank. Since the total score was not normally distributed, the association between immunohistochemistry score was analyzed using the Mann-Whitney test or Kruskal-Wallis one-way analysis of variance by ranks. $\mathrm{p}<0.05$ was considered statistically significant. Statistical analysis was performed using SPSS 20.0 statistical package.

\section{RESULTS}

HPLC analysis of lunasin

HPLC analysis of lunasin from Grobogan soybean was showed in Fig. 1 [19]

\section{Lunasin content of Grobogan soybean extract}

Lunasin content of the Grobogan soybean extract was measured in duplo, shown in Table 1, following previous studies [19]. 


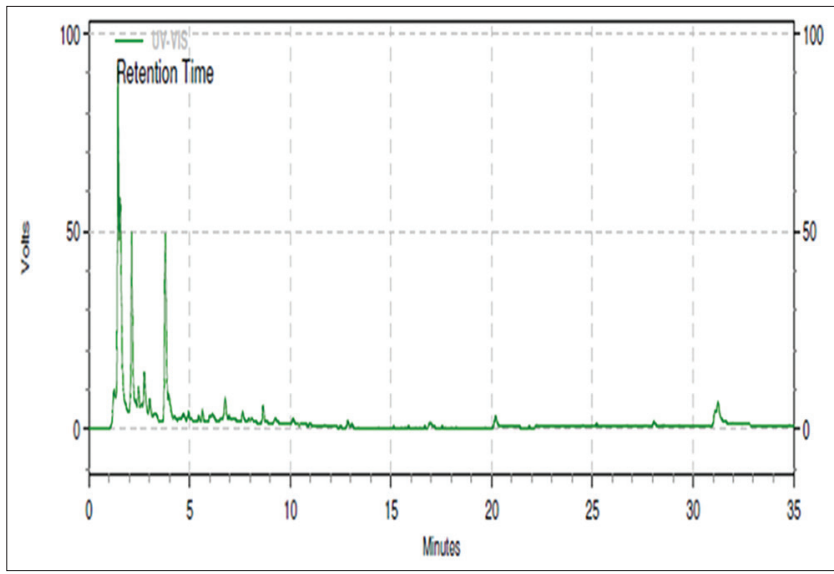

Fig. 1: High-performance liquid chromatography profile of lunasin from Grobogan soybean

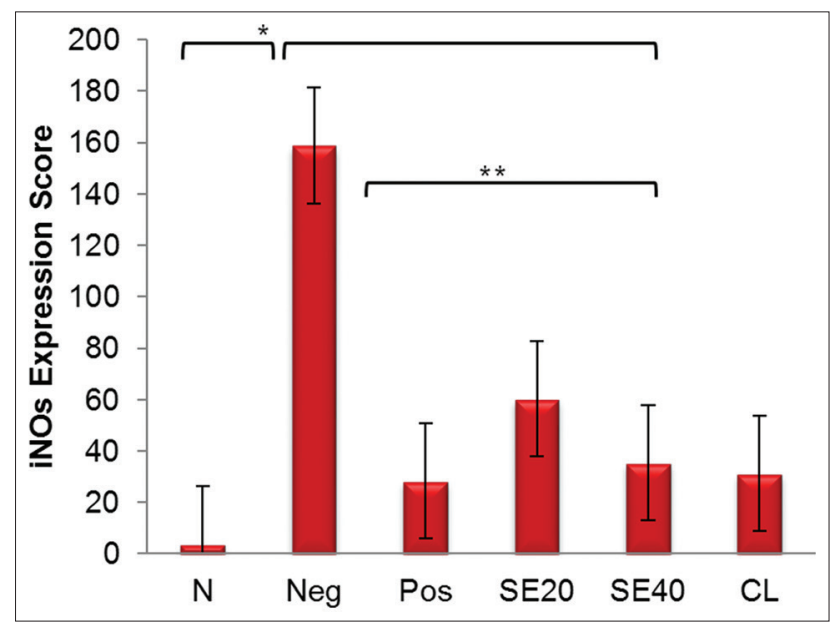

Fig. 2: Mean inducible nitric oxide synthase (iNOS) expressions score of mice crypt epithelial cells after induction of dextran sodium sulfate. ${ }^{*} p<0.05=$ significantly different compared to the negative control group. $* * p>0.05=$ no significant difference in iNOS expression score among the treatment groups
Effect of soybean extracts administration on iNOS expression Induction of DSS $2 \%$ can increase expression of iNOS in negative group which is significantly different from the normal group $(p=0.29)$. MannWhitney test shows statistically significant difference between the negative control group and SE1 group $(\mathrm{p}=0.29)$, SE2 group $(\mathrm{p}=0.29)$, and CL group $(\mathrm{p}=0.29)$. This shows that expression of iNOS caused induction of DSS $2 \%$ can be decreased by lunasin in soybean extract. Mann-Whitney test does not show statistically significant difference in iNOS expression score among the treatment groups. The effect of soybean extract administration on the iNOS expression is shown in Fig. 2. Expressions of iNOS in a colorectal epithelial cell of mice are shown in Fig. 3.

Effect of soybean extracts administration on $\boldsymbol{\beta}$-catenin expression Induction of DSS $2 \%$ can increase expression of $\beta$-catenin in negative group which is significantly different from the normal group $(p=0.29)$. Mann-Whitney test shows statistically significant difference between the negative control group and SE1 group ( $p=0.29)$, SE2 group ( $p=0.29)$, and CL group ( $\mathrm{p}=0.29)$. This show that expression of $\beta$-catenin caused induction of DSS $2 \%$ can be decreased by lunasin in soybean extract. Mann-Whitney test does not show statistically significant difference in $\beta$-catenin expression score among the treatment groups. The effect of soybean extract administration on the $\beta$-catenin expression is shown in Fig. 4. Expressions of $\beta$-catenin in colorectal crypt epithelial cell of mice are shown in Fig. 5.

\section{DISCUSSION}

Lunasin is one of the peptides found in soybeans. Previous research has proven that lunasin in soybean has various clinical effects such as anti-inflammation that is newly proven in vitro [15]. Based on that, this research is made to prove the activity of the active compound of lunasin in soybean as an anti-inflamatory agent in vivo seen from the expression of iNOS, and $\beta$-catenin in DSS-induced mice colon depicting IBD disease.

This study used Swiss Webster mice induced DSS to induce colonic inflammation. DSS can cause a colitis-like disease condition in a rat

Table 1: Lunasin content of the Grobogan soybean extract

\begin{tabular}{ll}
\hline Sample & Lunasin content $(\mathrm{mg} / \mathrm{g})$ \\
\hline Grobogan soybean extract & 0.808 \\
& 0.838 \\
\hline
\end{tabular}

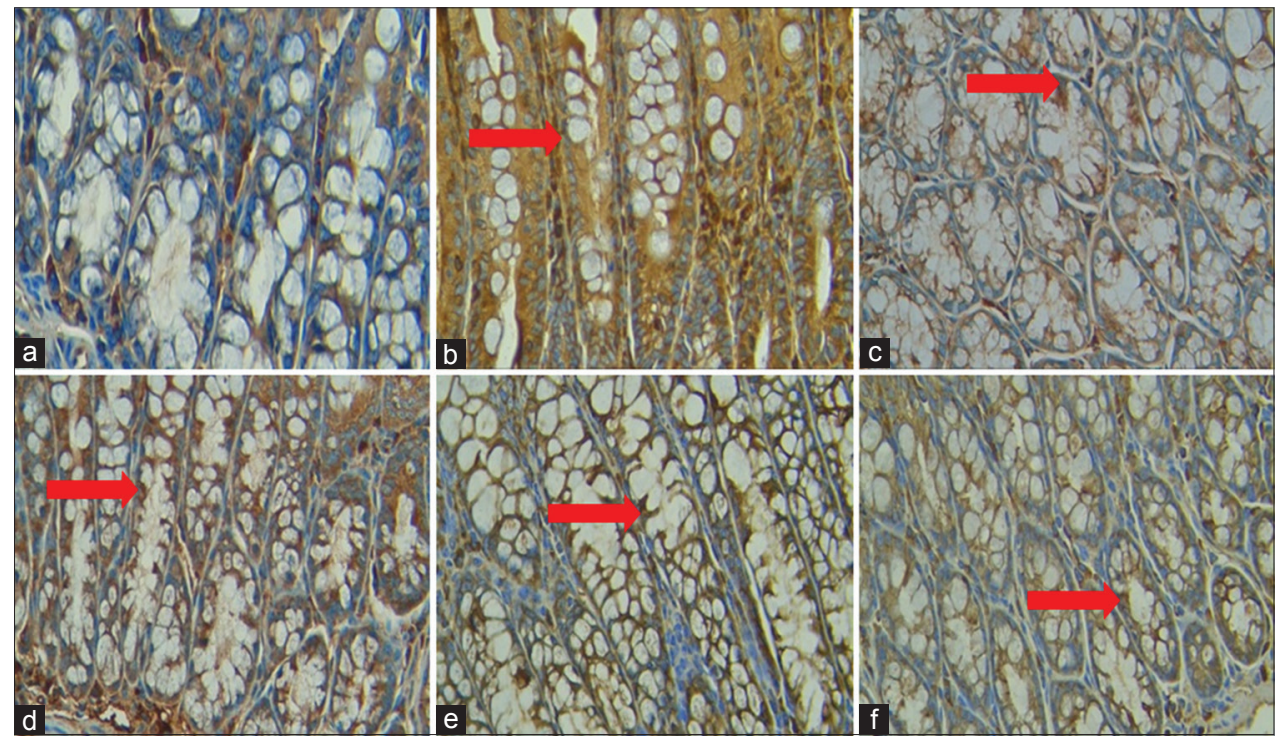

Fig. 3: Expressions of inducible nitric oxide synthase (iNOS) in colorectal epithelial cell of mice (magnification $\times 400)$. (a) Normal group,

(b) negative group, (c) positive group (Aspirin), (d) SE1 (lunasin $20 \mathrm{mg} / \mathrm{kgBW}$ ), (e) SE2 (lunasin $40 \mathrm{mg} / \mathrm{kgBW}$ ), and (f) commercial lunasin. The red arrows show iNOS expression in cytoplasm of colorectal epithelial cell 
model. The concentration of DSS and its molecular mass also play the vital role in colitis induction. The impact of DSS supplementation on colon tissues was assessed by histochemical studies. Both distal and proximal regions of the colon were examined with following parameters to measure the severity of the disease condition such as loss of epithelial, loss of mucosal architecture, mononuclear and polymorphonuclear cells in lamina propria, infiltration of inflammatory cells in submucosa, cryptitis and abscess formation, erosion or ulceration, and goblet cell depletion. This study suggests that DSS $5 \mathrm{KDa}$ can significantly increase inflammatory genes IL-6, TNF- $\alpha$, and iNOS [21].

Immunohistochemistry observations showed the highest expression of iNOs in DSS-induced groups. The high expression of iNOS in this group can be caused by administration of DSS to induce the expression of iNOS [22]. DSS can cause damage to mucosal epithelial barrier function and resulting in the entry of bacteria and antigens into the colonic mucosa, thus triggering the inflammatory response [23]. In the inflammatory reaction, the induced form of NO synthase (iNOS) has a considerable role. Inflammatory cells express iNOS in response to stimulation of cytokines such as IL-1 $\beta$ and IL- 6 in inflammatory reactions. The enzyme chains off the production of NO which have a

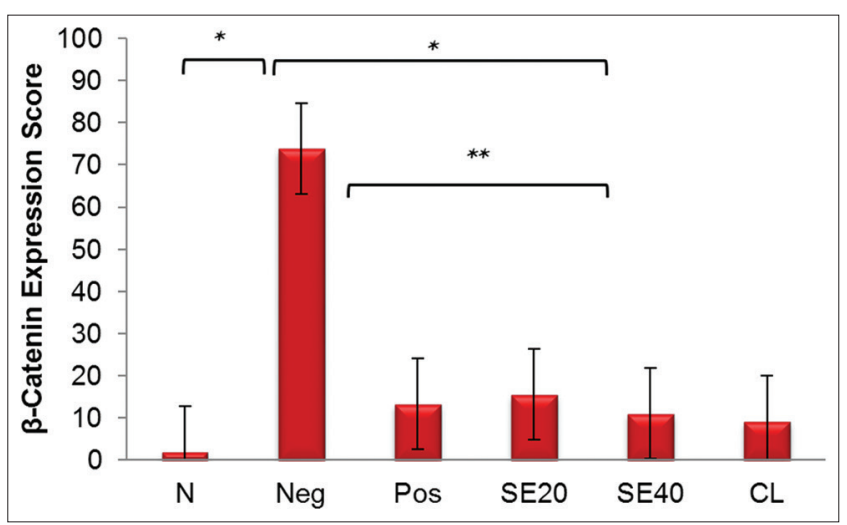

Fig. 4: Mean $\beta$-catenin expressions score of mice crypt epithelial cells after induction of dextran sodium sulfate. ${ }^{*} \mathbf{p}<0.05=$ significantly different compared to the negative control group. $* * p>0.05=$ no significant difference in $\beta$-catenin expression score among the treatment groups pro-inflammatory action vasodilator increases vascular permeability and stimulates prostaglandin production [24].

Suzuki et al. [25] showed that expression of nitrotyrosine was higher in DSS-induced mice of $2 \%$ and $1 \%$. Nitrotyrosine is a marker of the reaction between peroxynitrite and tyrosine proteins. Peroxynitrite is the result of the reaction of NO with superoxide (02) [25]. The high peroxynitrite showed high NO which proves the existence of iNOS as enzymes involved in the production of NO [24]. The results are consistent with the observations made in groups of mice induced by DSS.

Lunasin with a dose of $20 \mathrm{mg} / \mathrm{kgBW}$ and $40 \mathrm{mg} / \mathrm{kgBW}$ on soy extract can significantly reduce the expression of iNOs but not better than commercial aspirin and lunasin. This is probably due to the purity of commercial lunasin better than lunasin contained in soybean extract of Grobogan varieties.

Several studies have shown that lunasin has anti-inflammatory effects by decreasing the production of NO in the RAW 264.7 cells induced by LPS, which plays a role in the pathogenesis inflammation $[16,17]$. NO production decline due to a reduction in iNOS expression in inflammatory cells. Thus, lunasin plays a role in decreasing expression of iNOs which is one of the markers on the pathogenesis of inflammation. Results of other studies report that lunasin purified can decrease the expression of iNOS and COX-2 and inhibit the production of proinflammatory cytokines such as TNF-a, Interleukins-1 $\beta$ (IL-1 $\beta$ ), and NO in the RAW 264.7 cells induced by LPS [26].

There are several secondary metabolite compounds such as flavonoids and phenolics present in soybeans that potentially inhibit the expression of iNOs. The study reported by Laaboudi et al., mentions that phenolic compounds have anti-inflammatory activity [27]. While the study by Kazlowska et al., [28] mentions that the expression of iNOS in RAW 264.7 cells can be inhibited by flavonoid and phenolic compounds thus suppressing the production of NO.

In immunohistochemistry observations using $\beta$-catenin antibodies, the highest expression was in the DSS-induced negative control group of mice. The high expression of $\beta$-catenin may be due to the high production of iNOs in inflammatory conditions. Inflammation in the epithelial cells of the colon can lead to the formation of iNOS and COX-2, which resulted in upregulation of the production of NO and PGE2.

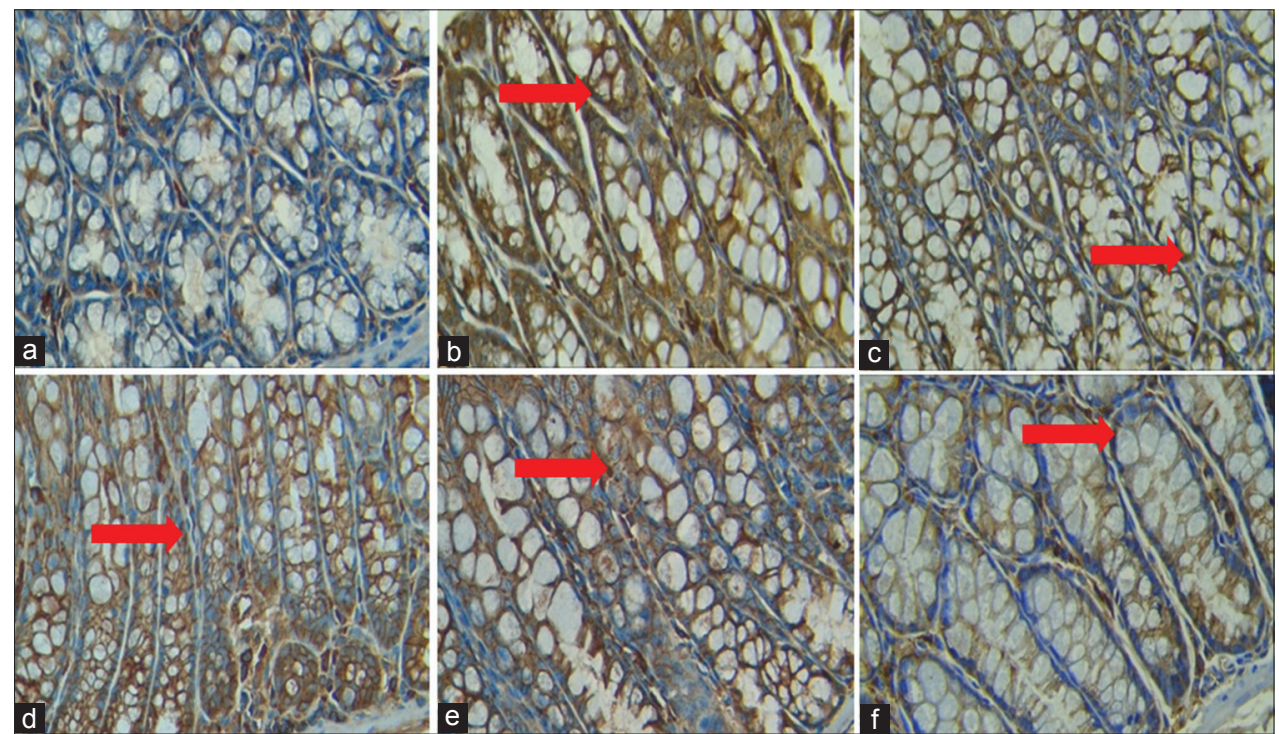

Fig. 5: Expressions of $\beta$-cateFig. 5: Expressions of $\beta$-catenin in colorectal crypt epithelial cell of mice (magnification $\times 400$ ). (a) Normal group, (b) negative group, (c) positive group nin in colorectal crypt epithelial cell of mice (magnification $\times 400)$. (a) Normal group,

(b) negative group, (c) positive group 
Both of these molecules cause increased ROS. ROS causes a variety of protooncogenic damage and tumor suppressor gene [8]. Damage caused by ROS stimulates the development of gene initiation in normal epithelial cells into cancer cells [9]. $\beta$-catenin is one of the suppressor gene tumors associated with the development of colon cancer. Under normal conditions, $\beta$-catenin is found in cell membranes and slightly in the cytoplasm and the nucleus. However, if there is a mutation in APC protooncogene, there will be an increase in the amount of $\beta$-catenin that can accumulate in the cytoplasm into the nucleus of epithelial cells kolon [10]. Therefore, in this study, the expression of $\beta$-catenin observed in the cytoplasm and nucleus that occur on the condition dysplasia. Increased $\beta$-catenin expression can be found in animals with DSS-induced dysplasia conditions and in humans with colitisassociated colon cancer [28]

Lunasin dose $20 \mathrm{mg} / \mathrm{kgBW}$ and $40 \mathrm{mg} / \mathrm{kgBW}$ can reduce the expression of $\beta$-catenin in mice induced by DSS, but not as good as commercial lunasin. The activity of lunasin as anti-inflammatory can decrease iNOs expression significantly. Decreased expression of iNOS in inflammatory cells likely to have a role in reducing the expression of $\beta$-catenin.

Lunasin is also known to have antioxidant activity. Lunasin was able to suppress the production of ROS in macrophages induced by LPS [16]. The decline in ROS production can reduce the damage and tumor suppressor gene protooncogene thus potentially reducing protooncogene mutations in the APC gene and over-expression on $\beta$-catenin so accumulated to the nucleus [8].

\section{CONCLUSION}

We have demonstrated that the administration of lunasin in the form of soybean extract in mice induced DSS can reduce expression of iNOS and $\beta$-catenin.

\section{ACKNOWLEDGMENTS}

We would like to thank Directorate of Research and Public Services Universitas Indonesia, for Multidiscepline 2015 Research Grand.

\section{REFERENCES}

1. Mattar MC, Lough D, Pishvaian MJ, Charabaty A. Current management of inflammatory bowel disease and colorectal cancer. Gastrointest Cancer Res 2011;4(2):53-61.

2. McConnell BB, Yang VW. The role of inflammation in the pathogenesis of colorectal cancer. Curr Colorectal Cancer Rep 2009;5(2):69-74.

3. Loftus EV Jr, Silverstein MD, Sandborn WJ, Tremaine WJ, Harmsen WS, Zinsmeister AR. Ulcerative colitis in Olmsted County, Minnesota, 1940-1993: Incidence, prevalence, and survival. Gut 2000;46(3):336-43.

4. Janakiram NB, Rao CV. The role of inflammation in colon cancer. Inflammation and Cancer. Switzerland: Springer Basel; 2014.

5. Lakatos PL, Lakatos L. Risk for colorectal cancer in ulcerative colitis: Changes, causes and management strategies. World J Gastroenterol 2008;14(25):3937-47.

6. Atreya I, Neurath MF. Immune cells in colorectal cancer: Prognostic relevance and therapeutic strategies. Expert Rev Anticancer Ther 2008;8(4):561-72.

7. Askling J, Dickman PW, Karlén P, Broström O, Lapidus A, Löfberg R, et al. Family history as a risk factor for colorectal cancer in inflammatory bowel disease. Gastroenterology 2001;120(6):1356-62.

8. Kusmardi MS, Priosoeryanto BP, Harlina E, Cornain S. Inhibition activities of fish oil in iNOs, COX-2, and $\beta$-Catenin expressions in colorectal preneoplasia of mice induced by azoxymetane and dextran sodium sulfate. J Appl Biotechnol 2014;2(2):91.

9. Ridnour LA, Thomas DD, Switzer C, Flores-Santana W, Isenberg JS, Ambs S, et al. Molecular mechanisms for discrete nitric oxide levels in cancer. Nitric Oxide 2008;19(2):73-6.

10. Gochman E, Mahajna J, Shenzer P, Dahan A, Blatt A, Elyakim R, et al. The expression of iNOS and nitrotyrosine in colitis and colon cancer in humans. Acta Histochem 2012;114(8):827-35.

11. Perše M, Cerar A. Dextran sodium sulphate colitis mouse model: Traps and tricks. J Biomed Biotechnol 2012;2012:718617.

12. Chassaing B, Aitken JD, Malleshappa M, Vijay-Kumar M. Dextran sulfate sodium (DSS)-induced colitis in mice. Curr Protoc Immunol 2014;14:15-25.

13. Dia VP, de Mejia EG. Lunasin potentiates the effect of oxaliplatin preventing outgrowth of colon cancer metastasis, binds to a5b1 integrin and suppresses $\mathrm{FAK} / \mathrm{ERK} / \mathrm{NF}-\mathrm{kB}$ signaling. Cancer Lett 2011;313:167-80.

14. Hernández-Ledesma B, Ben O, Hsieh CC. 1997-2012: Fifteen Years of Research on Peptide Lunasin. USA: INTECH Open Access Publisher; 2013.

15. Liu J, Jia SH, Kirberger M, Chen N. Lunasin as a promising healthbeneficial peptide. Eur Rev Med Pharmacol Sci 2014;18(14):2070-5.

16. Hernández-Ledesma B, Hsieh CC, de Lumen BO. Antioxidant and anti-inflammatory properties of cancer preventive peptide lunasin in RAW 264.7 macrophages. Biochem Biophys Res Commun 2009;390(3):803-8.

17. Dia VP, Wang W, Oh VL, De Lumen BO, De Mejia EG. Isolation, purification and characterisation of lunasin from defatted soybean flour and in vitro evaluation of its anti-inflammatory activity. Food Chem 2009;114(1):108-15.

18. de Mejia EG, Dia VP. Lunasin and lunasin-like peptides inhibit inflammation through suppression of NF-kappaB pathway in the macrophage. Peptides 2009;30(12):2388-98.

19. Amalia AW, Kusmardi S, Elya B, Arsianti A. Inhibition of carcinogenesis by seed and soybean meal extract in colon of mice : Apoptosis and dysplasia. Asian J Pharm Clin Res 2017;10(4):1-6.

20. Detre S, Jotti GS, Dowsett M. A "quickscore" method for immunohistochemical semiquantitation: Validation for oestrogen receptor in breast carcinomas. J Clin Pathol 1995;48(9):876-8.

21. Pengkumsri N, Suwannalert P, Sivamaruthi BS, Wongpoomchai R, Sirisattha S, Tammasakchai A, et al. Molecular, histological, and antioxidant evaluation of colitis induction in rats by different concentration of dextran sodium sulfate $(5 \mathrm{kda})$. Int $\mathrm{J}$ Pharm Pharm Sci 2015;7(12):283-7.

22. Tanaka T. Development of an inflammation-associated colorectal cancer model and its application for research on carcinogenesis and chemoprevention. Int J Inflam 2012;2012:1-16.

23. Kiesler P, Fuss IJ, Strober W. Experimental models of inflammatory Bowel Diseases. Cell Mol Gastroenterol Hepatol 2015;1(2):154-70.

24. Nugroho AE. Farmakologi: Obat-obat Penting Dalam Pembelajaran Ilmu Farmasi dan Dunia Kesehatan. Yogyakarta: Pustaka Pelajar; 2012.

25. Suzuki R, Kohno H, Sugie S, Nakagama H, Tanaka T. Strain differences in the susceptibility to azoxymethane and dextran sodium sulfate-induced colon carcinogenesis in mice. Carcinogenesis 2006;27(1):162-9

26. Liu CF, Pan TM. Recombinant expression of bioactive peptide lunasin in Escherichia coli. Appl Microbiol Biotechnol 2010;88(1):177-86.

27. Laaboudi W, Ghanam J, Aissam H, Merzouki M, Benlemlih M. Antiinflammatory and ananlgesic activities of olive tree extract. Int J Pharm Pharm Sci 2016;8(7):414-9.

28. Serafino A, Moroni N, Zonfrillo M, Andreola F, Mercuri L, Nicotera G, et al. WNT-pathway components as predictive markers useful for diagnosis, prevention and therapy in inflammatory bowel disease and sporadic colorectal cancer. Oncotarget 2014;5(4):978-92. 